\title{
On the Absorption of Glucose into the Portal Vein in Splenectomized Dogs.
}

\author{
$\mathrm{By}$ \\ Hidekazu Tanaka and Keisiro Saizyo. \\ (田中英一) (西條圈四郎) \\ (From the Physiological Laboratory of Prof. Y. Satake, \\ Tohoku Imperial University, Sendai.)
}

Being led by the view, apparently generally accepted, that removal of the spleen induces a reduced sugar tolerance of animals, we attempted to determine whether or not the velocity with which glucose is absorbed into the portal vein is modified by splenectomy, the data of Satake and Fujii in this laboratory ${ }^{1)}$ on normal dogs being taken as the control. It must be said here that we were not able to affirm the view, above related, in the case of cats, as reported before. ${ }^{2}$

\section{Methods.}

Adult dogs, male or female (non-pregnant), were used. As to the general procedures, they were almost similar to the previous work of Satake and Fujii, except that the place where the abdominal cavity was opened for preparing the portal vein was different.

For avoiding any use of narcotica and pain, the dorsal spinal roots from the fourth thoracic to the second lumbar cord were previously divided. And the great auricular nerve was sectioned unilaterally for taking blood samples without causing pain.

After recovery of the animals, the spleen was taken out after laparotomy without or with narcosis.

Glucose experiment was carried out two or three weeks after splenectomy. The dog was fastened on the table supine, a metal cannula was inserted into the stomach through a brief median incision which was closed soon, and then the abdominal cavity was reopened

1) Satake and Fujii, Tohoku J. of Exp. Med., 1926, 7, 522.

2) Ta naka, Ibid., 1937, 30, 203. 
through an incision, diagonal from lateral above to median below, of about $10 \mathrm{cms}$. long, laid in the right lateral abdominal region, through which the portal vein is readily caught, much easier than through the median incision, as S. \& F. did. The wound was temporarily closed by means of arterial forceps or silk threads, then the dog was freed, and when blood samples were to be collected from the portal vein, the dog was simply laid down on its left side; never fastened. The dogs were in pretty good condition throughout the whole experimental course.

Glucose (Merck) was given into the stomach through the fistula in a fixed dose of 2.5 grms. per kilo of body weight, as 10 per cent solution, warmed at about $37^{\circ}$.

Blood samples from the portal vein and the ear vein were determined for glucose by the $\mathrm{Hagedorn}$ and Jensen method. When the experiment was terminated, the stomach content was taken out through the fistula and estimated for reducing power by the Bertrand method. Vomiting did not occur in any case.

Results.

Experiment $I$. 2 weeks after splenectomy glucose was administered. Before, it the sugar in the portal vein was $0.107 \%$, that in the ear vein $0.098 \% .15$ minutes after glucose introduction the sugar contents increased to $0.155 \%$ and $0.132 \%$ respectively, afterwards they continued to increase further, so that just two hours after the introduction the acme, such as $0.184 \%$ and $0.155 \%$ respectively, was reached. Then they declined, one hour later $0.134 \%$ and $0.119 \%$, two hours $0.119 \%$ and $0.110 \%$; afterwards they decreased further but slowly. 6 hours after the introduction $0.86 \mathrm{grm}$. sugar was found remaining in the stomach, against 57 grms. sugar, introduced.

Experiment II. Two weeks after splenectomy, the initial blood sugar was $0.105 \%$ in the portal vein, and $0.093 \%$ in the ear vein. On receiving glucose solution, the sugar content in the bloods increased only slowly, so that 15 minutes after the introduction $0.114 \%$ and $112 \%, 30$ minutes $0.112 \%$ and $0.107 \%$ were noted, but then somewhat rapidly $0.183 \%$ and $0.138 \%$, the acme in both kinds of blood, were measured just two hours after the introduction; the sugar concentration in both bloods was then afterwards measured as lying almost within the limits in the non-digestive period. 6 hours after the introduction glucose was remaining in the stomach in 10 per cent of the amount introduced. 


\section{Experiment I.}

Dog, male.

27. $X .1934 .25$ kilos. $T_{10}-T_{4}$ dorsal spinal roots bilaterally divided.

25. I. 1935.22 kilos. $T_{11}-L_{2}$ dorsal spinal roots bilaterally divided.

21. II. 1935. Splenectomy.

8. III. 1935. 23 kilos. Glucose-experiment:

\begin{tabular}{|c|c|c|c|c|c|}
\hline \multirow{2}{*}{ Time } & \multirow{2}{*}{$\begin{array}{l}\text { Room } \\
\text { temp. } \\
\left({ }^{\circ} \mathrm{C} \text {. }\right)\end{array}$} & \multicolumn{2}{|c|}{$\begin{array}{l}\text { Blood sugar } \\
\quad(\%) \text { in }\end{array}$} & \multirow{2}{*}{$\begin{array}{l}\text { Anal } \\
\text { temp. } \\
\left({ }^{\circ} \mathrm{C} .\right)\end{array}$} & \multirow{2}{*}{ Remarks } \\
\hline & & $\begin{array}{c}\text { portal } \\
\text { vein }\end{array}$ & $\begin{array}{c}\text { ear } \\
\text { vein }\end{array}$ & & \\
\hline $\begin{array}{l}9: 30 \mathrm{a} \cdot \mathrm{m} . \\
9: 35 \\
9: 50-10: 40\end{array}$ & 20 & & 0.095 & 39.1 & $\begin{array}{l}\text { Fastened on the board. } \\
\text { Laparotomy, gastric fistula, preparing of the } \\
\text { portal vein. } \\
\text { No excitement. }\end{array}$ \\
\hline $\begin{array}{l}12: 35 \mathrm{p} . \mathrm{m} . \\
12: 50\end{array}$ & 20 & 0.107 & 0.098 & 39.0 & 57 grms. glucose in 570 c.c. water (about $37^{\circ} \mathrm{C}$. \\
\hline $\begin{array}{l}1: 5 \\
1: 20\end{array}$ & 20 & $\begin{array}{l}0.155 \\
0.170\end{array}$ & $\begin{array}{l}0.132 \\
0.140\end{array}$ & & Portal vein blood clotted with readiness. \\
\hline $\begin{array}{l}1: 50 \\
2: 20\end{array}$ & & $\begin{array}{l}0.167 \\
0.172\end{array}$ & $\begin{array}{l}0.145 \\
0.142\end{array}$ & & 2:0 Dog crying for some minutes. \\
\hline 2:50 & 21 & 0.184 & 0.155 & 39.1 & \\
\hline $3: 50$ & 22 & 0.134 & 0.119 & 39.2 & \\
\hline $4: 50$ & 20 & 0.119 & 0.110 & 39.3 & \\
\hline $5: 50$ & 20 & 0.121 & 0.110 & 39.0 & \\
\hline $6: 50$ & 16 & 0.114 & 0.107 & 38.7 & $\begin{array}{l}\text { Portal vein blood-clotting almost normal. } \\
\text { Stomach content about } 55 \text { c.c. with } 1.54 \% \\
\text { sugar }(0.84 \mathrm{grm} \text {. sugar in toto). }\end{array}$ \\
\hline
\end{tabular}

Experiment II.

Dog, male.

12. XII, 1934.18 kilos. $\mathrm{L}_{2}-\mathrm{T}_{10}$ dorsal spinal roots bilaterally dirided.

15. I. 1935.15 kilos. $\mathrm{T}_{9}^{-}-\mathrm{T}_{4}$ dorsal spinal roots bilaterally divided.

1. III. 1935. Splenectoms.

15. III. 1935. 16 kilos. Glucose-experiment.

\begin{tabular}{|c|c|c|c|c|c|}
\hline \multirow{2}{*}{ Time } & \multirow{2}{*}{$\begin{array}{l}\text { Room } \\
\text { temp. } \\
\left({ }^{\circ} \mathrm{C} .\right)\end{array}$} & \multicolumn{2}{|c|}{$\begin{array}{l}\text { Blood sugar } \\
(\%) \text { in }\end{array}$} & \multirow{2}{*}{$\begin{array}{l}\text { Anal } \\
\text { temp. } \\
\left({ }^{\circ} \mathrm{C} .\right)\end{array}$} & \multirow{2}{*}{ Remarks } \\
\hline & & $\begin{array}{c}\text { portal } \\
\text { vein }\end{array}$ & $\begin{array}{c}\text { ear } \\
\text { vein }\end{array}$ & & \\
\hline $\begin{array}{l}9: 50 \text { a.m. } \\
9: 52 \\
10: 4 \\
10: 15-10: 55\end{array}$ & $\begin{array}{l}16 \\
16\end{array}$ & & $\begin{array}{l}0.087 \\
0.100\end{array}$ & 39.1 & $\begin{array}{l}\text { Fastened on the board. } \\
\text { Laparotomy, gastric fistula, preparing of the } \\
\text { portal vein. Quiet. }\end{array}$ \\
\hline $\begin{array}{l}1: 0 \mathrm{p} \cdot \mathrm{m} . \\
1: 5 \\
1: 20\end{array}$ & 17 & 0.114 & $\begin{array}{l}0.093 \\
0.112\end{array}$ & 39.5 & $\begin{array}{l}40 \text { grms. glucose in } 400 \text { c.c. water (about } 37^{\circ} \mathrm{C} \text {. } \\
\text { warm) into stomach ( } 2.5 \text { grms. per kilo). }\end{array}$ \\
\hline
\end{tabular}




\begin{tabular}{|c|c|c|c|c|c|}
\hline \multirow{2}{*}{ Time } & \multirow{2}{*}{$\begin{array}{c}\text { Room } \\
\text { temp. } \\
\left({ }^{\circ} \mathrm{C} .\right)\end{array}$} & \multicolumn{2}{|c|}{$\begin{array}{l}\text { Blood sugar } \\
(\%) \text { in }\end{array}$} & \multirow{2}{*}{$\begin{array}{c}\text { Anal } \\
\text { temp. } \\
\left({ }^{\circ} \mathrm{C} .\right)\end{array}$} & \multirow{2}{*}{ Remarlis } \\
\hline & & $\begin{array}{c}\text { portal } \\
\text { vein }\end{array}$ & $\begin{array}{l}\text { ear } \\
\text { vein }\end{array}$ & & \\
\hline 1:35 p.m. & 19 & 0.112 & 0.107 & 39.0 & \\
\hline $2: 5$ & & 0.146 & 0.112 & & \\
\hline $2: 35$ & 20 & 0.165 & 0.127 & 39.0 & \\
\hline $3: 5$ & & 0.183 & 0.138 & & Dog sleepy. \\
\hline $4: 5$ & 21 & 0.119 & 0.093 & 39.0 & \\
\hline $5: 5$ & & 0.107 & 0.093 & & \\
\hline $6: 5$ & 19 & 0.114 & 0.096 & 38.6 & \\
\hline $7: 5$ & 18 & 0.102 & 0.093 & 38.6 & $\begin{array}{l}\text { Stomach content about } 130 \text { c.c. with } 3 \% \text { sugar } \\
\text { (3.9 grms. sugar in toto). }\end{array}$ \\
\hline
\end{tabular}

Dog, male.

Experiment III.

25. I. 1935. 17 kilos. $L_{2}-T_{10}$ dorsal spinal roots bilaterally divided.

22. II. 1935.17 kilos. $\mathrm{T}_{9}-\mathrm{T}_{4}$ dorsal spinal roots bilaterally divided.

13. III. $1935 . \quad$ Splenectomy.

5. IV. 1935,16 kilos. Glucose-experiment.

\begin{tabular}{|c|c|c|c|c|c|}
\hline \multirow{2}{*}{ Time } & \multirow{2}{*}{$\begin{array}{l}\text { Room } \\
\text { temp. } \\
\left({ }^{\circ} \mathrm{C} .\right)\end{array}$} & \multicolumn{2}{|c|}{$\begin{array}{l}\text { Blood sugar } \\
(\%) \text { in }\end{array}$} & \multirow{2}{*}{$\begin{array}{c}\text { Anal } \\
\text { temp. } \\
\left({ }^{\circ} \mathrm{C} .\right)\end{array}$} & \multirow{2}{*}{ Remarks } \\
\hline & & $\begin{array}{l}\text { porta] } \\
\text { vein }\end{array}$ & $\begin{array}{l}\text { ear } \\
\text { vein }\end{array}$ & & \\
\hline $\begin{array}{c}9: 40 \text { a.m. } \\
9: 50 \\
10: 10-10: 35\end{array}$ & 18 & & 0.126 & & $\begin{array}{l}\text { Fastened on the board. } \\
\text { Dog somewhat sensitive and sometimes excited. } \\
\text { Lanarotomy, gastric fistula, preparing of the } \\
\text { portal vein. } \\
\text { During the operation the dog sometimes ex- } \\
\text { cited a little. }\end{array}$ \\
\hline $10: 40$ & 18 & & 0.128 & 40.0 & \\
\hline $\begin{array}{l}1: 5 \mathrm{p} . \mathrm{m} \\
1: 15\end{array}$ & 19 & 0.105 & 0.104 & 39.5 & $\begin{array}{l}40 \text { grms. glucose in } 400 \text { c.c. water (about } 37^{\circ} \mathrm{C} \text {. } \\
\text { warm) into stomach }(2.5 \text { grms. per kilo). }\end{array}$ \\
\hline $\begin{array}{l}1: 30 \\
1: 45\end{array}$ & 19 & $\begin{array}{l}0.118 \\
0.125\end{array}$ & $\begin{array}{l}0.110 \\
0.115\end{array}$ & 39.5 & $\begin{array}{l}\text { During the whole experiment the dog some- } \\
\text { times excited and cried. }\end{array}$ \\
\hline $2: 15$ & 20 & 0.125 & 0.112 & 39.4 & \\
\hline $2: 45$ & & 0.135 & 0.119 & & \\
\hline $3: 15$ & 20 & 0.128 & 0.112 & 39.6 & \\
\hline $4: 15$ & & 0.118 & 0.108 & 39.7 & \\
\hline $5: 15$ & 20 & 0107 & 0.111 & 39.8 & Somewhat excited. \\
\hline $6: 16$ & 20 & 0.111 & 0.111 & 40.0 & Excited. \\
\hline $7: 15$ & 19 & 0.104 & 0.100 & 40.0 & Stomach content was not found. \\
\hline
\end{tabular}

Experiment III. Three weeks were allowed to elapse after splenectomy till the absorption experiment. Before glucose the sugar content in both kinds of venous blood, portal and auricular, was the same $(0.105 \%$ \& $0.104 \%)$. On administering glucose the sugar content increased but slowly and rather insignificantly, so that $0.135 \%$ and 
$0.119 \%$, respectively, determined one and a half hours after the introduction were the peaks; afterwards it recovered the initial value slowly. No rest of glucose was found in the stomach 6 hours after the introduction.

Experiment $\Pi T$. The absorption experiment was carried out also three weeks after loss of the spleen. The outcome was very similar in general to that in Experiment III; only a little greater were the maximum values $(0.145 \% \& 0.124 \%)$, which were attained two hours after the introduction. 2 grms. sugar was discovered in the stomach content 6 hours after having introduced 32 grms. glucose.

Dog, male.

$$
\text { Experiment IV. }
$$

19. XII. 1934.15 kilos. $\mathrm{L}_{0}-\mathrm{T}_{10}$ dorsal spinal roots bilaterally divided.

18. I. 1935.14 kilos. $\mathrm{T}_{9}-\mathrm{T}_{4}$ dorsal spinal roots bilaterally divided.

1. III. 1935 .

Left $n$. auriculáris mag. cut.

22. III. 1935. 13 kilos. Glucose-Experiment.

\begin{tabular}{|c|c|c|c|c|c|}
\hline \multirow{2}{*}{ Time } & \multirow{2}{*}{$\begin{array}{l}\text { Room } \\
\text { temp. } \\
\left({ }^{\circ} \mathrm{C} .\right)\end{array}$} & \multicolumn{2}{|c|}{$\begin{array}{l}\text { Blood sugar } \\
(\%) \text { in }\end{array}$} & \multirow{2}{*}{$\begin{array}{l}\text { Anal } \\
\text { temp. } \\
\left({ }^{\circ} \mathrm{C} .\right)\end{array}$} & \multirow{2}{*}{ Remarks } \\
\hline & & $\begin{array}{c}\text { portal } \\
\text { vein }\end{array}$ & $\begin{array}{c}\text { ear } \\
\text { vein }\end{array}$ & & \\
\hline $\begin{array}{l}9: 45 \text { a.m. } \\
9: 50 \\
9: 55 \\
10: 10-10: 35\end{array}$ & 19 & & $\begin{array}{l}0.105 \\
0.108\end{array}$ & & $\begin{array}{l}\text { Fastened on the board. } \\
\text { Laparotomy, gastric fistula, preparing of the } \\
\text { portal vein. } \\
\text { No sign of pain. }\end{array}$ \\
\hline $\begin{array}{l}12: 55 \mathrm{p} . \mathrm{m} . \\
1: 3\end{array}$ & 19 & 0.115 & 0.108 & 39.3 & $\begin{array}{l}32 \text { grms. glucose in } 320 \text { c.c. water (about } 37^{\circ} \mathrm{C} \text {. } \\
\text { warm) into stomach ( } 2.5 \text { grms. per kilo). } \\
\text { Now and then a little excited. }\end{array}$ \\
\hline $1: 18$ & 20 & 0.118 & 0.111 & 39.1 & Now and then a little excited. \\
\hline $\begin{array}{l}1: 33 \\
2: 3\end{array}$ & & $\begin{array}{l}0.122 \\
0.127\end{array}$ & $\begin{array}{l}0.113 \\
0.113\end{array}$ & & $\cdot$ \\
\hline $2: 33$ & 20 & 0.141 & 0.117 & 38.4 & Nausea, but no vomiting. \\
\hline $3: 3$ & 20 & 0.145 & 0.124 & 38.4 & \\
\hline $4: 3$ & 21 & 0.117 & 0.119 & 38.2 & \\
\hline $5: 3$ & 20 & 0.101 & 0.108 & 38.0 & \\
\hline $6: 3$ & 19 & 0.105 & 0.105 & 37.5 & Stomach content about 65 c.c. with $3.4 \%$ sugar \\
\hline $7: 3$ & 18 & 0.105 & 0.108 & 37.4 & ( 2.2 grms. sugar in toto) \\
\hline
\end{tabular}

In another experiment on 29. XI. 1934, the spleen was removed after preparing the stomach fistula, the portal vein, and one hour later glucose was introduced, this time the absorption was observed as going irregularly; the sugar content of the portal vein, for example, $0.098 \%$ before introduction, $0.110 \% 5$ minutes after introduction, $0.116 \% 30$ minutes after the introduction, $0.095 \% 1$ hour, $0.091 \% 1.5$ hours \& 2 hours, $0.109 \% 3$ hours, $0.143 \% 4$ hours, $0.125 \% 5$ hours, and $0.161 \% 6$ hours. This case will not be taken into general consideration. 
In general the portal and ear vein blood increased their sugar content soon on introducing glucose in the stomach through the fistula, and reached the maximum almost 2 hours after the introduction. 2.5 gr'ms. glucose per kilo was the dosage and $0.18-0.13 \%$ sugar were the maximum values in the portal vein blood and $0.15-0.12 \%$ in the ear vein blood. The hyperglycaemia covers commonly about three to six hours.

If these figures be compared with those of Satake and Fujii, who made use of similar procedures with us, only with a difference that they fastened dogs on the board in a supine position throughout the whole experimental course, whereas the present writer set the dogs free on the table lying on their left side, as shown in the accompanying table and figure giving the averages, it must be recognized

\section{TABLE.}

Comparison of the blood sugar fluctuations on the glucose administration in normal dogs and splenectomized dogs.

\begin{tabular}{l|l|l|l|l|l|l|l|l|}
\hline $\begin{array}{c}\text { No. of } \\
\text { experiment }\end{array}$ & \multicolumn{5}{|c}{ After the glucose administration } \\
\cline { 2 - 5 } & Before $15 \mathrm{~min} .30 \mathrm{~min}$. & $1 \mathrm{~h}$. & $1.5 \mathrm{~h}$. & $2 \mathrm{~h}$. & $3 \mathrm{~h}$. & $4 \mathrm{~h}$. & $6 \mathrm{~h}$. & $6 \mathrm{~h}$. \\
\hline
\end{tabular}

(A) In portal vein blood.

\begin{tabular}{|c|c|c|c|c|c|c|c|c|c|c|}
\hline I. $\delta$ & 0.107 & 0.155 & 0.170 & 0.167 & 0.172 & 0.184 & 0.134 & 0.119 & 0.121 & 0.111 \\
\hline II. $\hat{o}$ & 0.105 & 0.114 & 0.112 & 0.146 & 0.165 & 0.183 & 0.119 & 0.107 & 0.114 & 0.102 \\
\hline III. $\delta$ & 0.105 & 0.118 & 0.125 & 0.125 & 0.135 & 0.128 & 0.118 & 0.107 & 0.111 & 0.104 \\
\hline IV. $\hat{\delta}$ & 0.115 & 0.118 & 0.122 & 0.127 & 0.141 & 0.145 & 0.117 & 0.101 & 0.105 & 0.105 \\
\hline Average & 0.108 & 0.126 & 0.132 & 0.141 & 0.153 & 0.160 & 0.122 & 0.109 & 0.113 & 0.106 \\
\hline
\end{tabular}

\begin{tabular}{|c|c|c|c|c|c|c|c|c|c|c|}
\hline I. $\hat{o}$ & 0.09 & 0.24 & 0.18 & - & 0.16 & 0.14 & 0.12 & 0.07 & & - \\
\hline & 0.10 & 0.13 & 0.17 & 0.13 & 0.10 & - & - & 0.11 & 0.09 & 0.06 \\
\hline III. $\delta$ & 0.08 & 0.16 & 0.15 & 0.16 & 0.11 & 0.11 & 0.09 & 0.07 & 0.07 & 0.07 \\
\hline IV. $\hat{0}$ & 0.09 & 0.16 & 0.18 & 0.20 & 0.19 & 0.20 & 0.15 & 0.11 & 0.10 & 0.08 \\
\hline V. 9 & 0.10 & 0.21 & 0.22 & 0.17 & 0.19 & 0.13 & 0.12 & 0.11 & 0.10 & \\
\hline & 0.09 & 0.18 & 0.18 & 0.16 & 0.15 & 0.14 & 0.12 & 0.09 & 0.09 & 8 \\
\hline
\end{tabular}

(B) In ear vein blood.

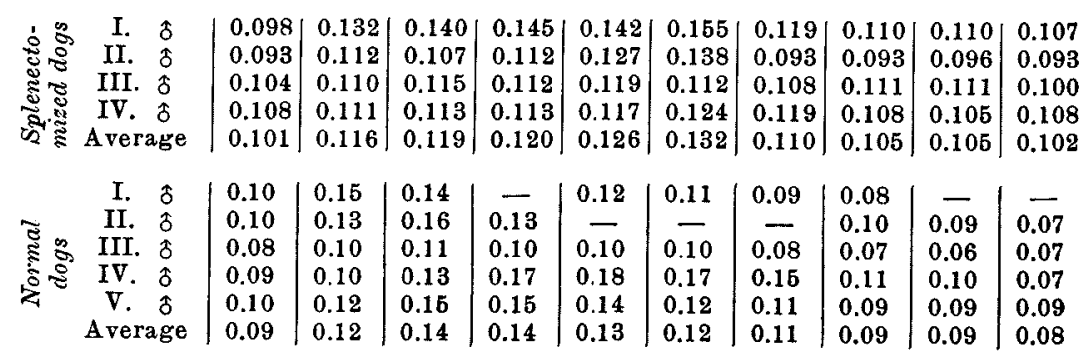

The date of normal dogs are those of $\mathrm{S}$ atake and $\mathrm{Fuji}$ in this laboratory. 


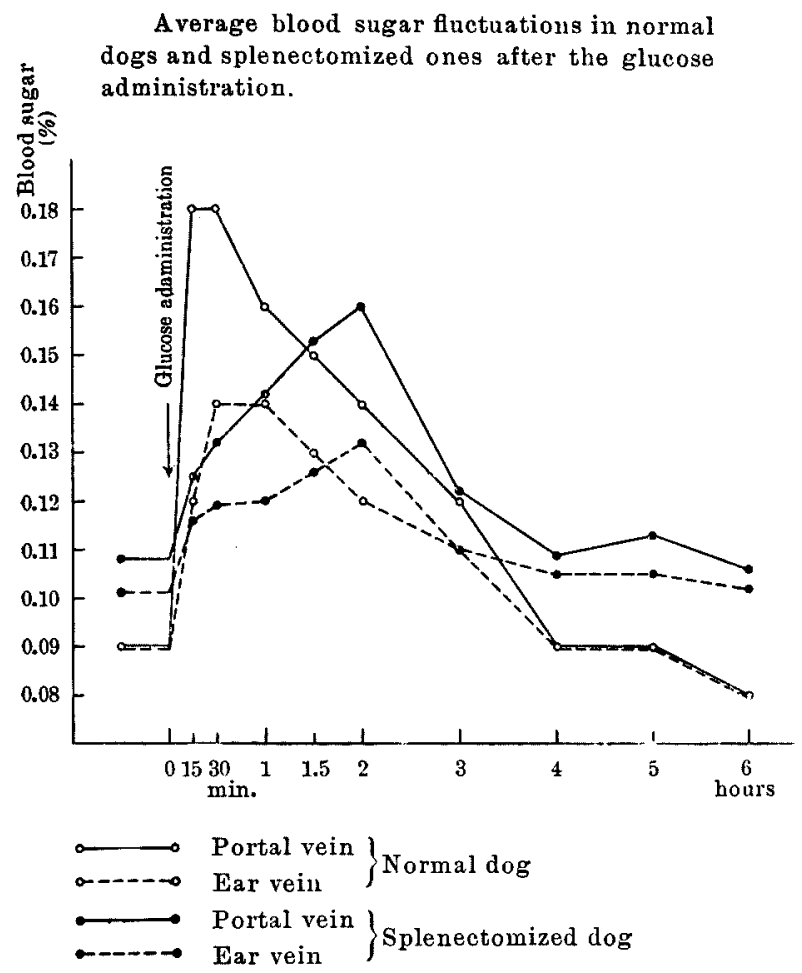

that the alimentary hyperglycaemia occurring in the portal vein blood and the general venous blood as well, is somewhat smaller and appears somewhat retarded in the present investigations, viz. in the dogs splenectomized, but the duration of alimentary hyperglycaemia is similar in both kinds of dogs, normal and splenectomized.

Their outcome from the normal dogs find similarity in some previous reports ${ }^{3}{ }^{3}$ although the experimental conditions were somewhat different.

\section{Summary.}

In the dogs, the operation field of which was sufficiently previously de-afferented, the spleen was excised per laparotomiam, two or three weeks later was tested without applying any anaesthesia absorption of glucose, which was introduced into the stomach through the fistula prepared at once per laparotomiam. The sugar content of the portal and ear vein bloods was determined systematically, and compared to the figures obtained previously in our laboratory. The sole difference in both sets of experiments, the previous and the present, was that the previous observers fastened dogs supine on the table while we let dogs lie on their left side.

3) Kotschneff, Pfügers Arch., 1923, 201, 365; Albertoni, Ergeb. d. Physiol., $1914,14,441$. 
The increase of the sugar content in both kinds of blood, portal and auricular, was this time, that is, in the splenectomized dogs, somewhat smaller and arrived at its peak somewhat later; otherwise expressed, the alimentary hyperglycaemia observable in the portal vein blood and the general vein blood was somewhat smaller and progresses somewhat slowly in the splenectomized dogs, but the duration of the hyperglycaemia was similar in the normal and the splenectomized dogs.

In passing it may be noted that we were not able to find a diminution of the sugar tolerance by removal of the spleen in our dogs. 